\title{
Wczesna edukacja dziecka z perspektywy wybranych doświadczeń i badań studenckich
}

Wiele w ostatnich latach powiedziano o edukacji najmłodszych, szczególnie w kontekście tego jak powinna i czy przekształca się ona w związku z nowymi oczekiwaniami. Oczekiwania dotyczą zarówno zmiany podejścia do dziecka, jak i instytucjonalnych warunków wychowania i kształcenia. Oczywiste jest, że wymogi formalno-organizacyjne można zadekretować przepisami prawa i wyegzekwować. Natomiast zmiany nauczycielskiej postawy i zachowań nie da się w żaden sposób zewnętrznie zarządzić. Wymaga ona przede wszystkim zrozumienia na czym polega istota rzeczy, czym różni się osobista praktyka zawodowa od tej postulowanej. A to z kolei nie jest możliwe bez krytycznego przyglądania się różnym aspektom rzeczywistości edukacyjnej własnej i innych.

Prezentowane tu interpretacje wyrosły z przyglądania się kształceniu akademickiemu ${ }^{1}$. Zaistniały przy tej okazji sytuacje, które skierowały moją uwagę $\mathrm{w}$ inną stronę, tj. na to, w jaki sposób studentki ${ }^{2}$ postrzegają przedszkole i edukację początkową. Jaki obraz wyłania się ze studenckich relacji i sądów oraz czy kontrastuje on $\mathrm{z}$ obrazem wynikającym $\mathrm{z}$ badań naukowych? Interesujące było również, co powoduje nadawanie przez studentki określonego znaczenia obserwowanej rzeczywistości edukacyjnej. I tak, od 2008 r. w 6 grupach studenckich specjalności pedagogika wczesnoszkolna z wychowaniem przedszkolnym $^{3}$ skoncentrowałam się na odnotowywaniu i analizie tych zdarzeń, relacji z badań oraz opinii, które uznałam za specyficzne dla postrzegania wczesnej edukacji. Dane pochodzą z obserwacji zdarzeń krytycznych oraz jakościowej

\footnotetext{
${ }^{1}$ Chodziło o określenie trudności pojawiających się w związku z projektowaniem oraz realizacją przez studentki pedagogicznych badań własnych, które prowadzą w Szkole Wyższej im. B. Jańskiego w ramach różnych przedmiotów (np. edukacja przez projekty, metody badań i seminarium dyplomowe).

${ }^{2} \mathrm{Z}$ racji specjalności były to - poza dwoma wyjątkami, które w tych badaniach nie są uwzględnione - kobiety.

${ }^{3}$ Były to grupy seminaryjne (6 i 7 semestr) i grupy realizujące projekty działań lub badawcze (5 semestr) - 108 studentów, w tym 41 studiów stacjonarnych.
} 
analizy tekstów studenckich. Ponadto, z wywiadów indywidualnych i grupowych dyskusji prowokowanych wcześniej zarejestrowanymi obserwacjami ${ }^{4}$.

\section{Relacje i interpretacje - edukacja wczesnoszkolna}

Sekwencja zdarzeń 1. W związku ze swymi zamierzeniami badawczymi studentka ${ }^{5}$ udała się do warszawskiej szkoły. W klasie tej zajęcia prowadzą dwie nauczycielki. Jedna, będąca dyrektorem szkoły, realizuje wyłącznie zakres treści określony dla edukacji matematycznej. Inna pozostałe zajęcia. Fakt ten nie zdziwił studentek, mimo że od początku reformy I etap edukacyjny z założenia powinien być realizowany przez jedną osobę. Oceniły sytuację jako naturalną, choć zwracały uwagę, iż ze względu na dobro dziecka klasa powinna być powierzona jednej nauczycielce. Były też przekonane, że decyzje należą do dyrektora szkoły - władzy oświatowej, jak się wyraziły, który może zrobić jak uzna za stosowne. To pokazuje wiarę $\mathrm{w}$ moc sprawczą zarządzających oraz chyba jednak nieznajomość podstaw prawno-administracyjnych funkcjonowania edukacji. Przepisy poprzedzające najnowsze regulacje dopuszczały taką możliwość ${ }^{6}$. Obecnie, poza edukacją muzyczną, plastyczną, wychowaniem fizycznym, zajęciami komputerowymi i językiem obcym oraz elementami edukacji zdrowotnej, inne wyodrębnianie przedmiotów nie jest uprawnione ${ }^{7}$. Trzeba przyznać, że wymogi te pozostają w sprzeczności z sytuacją kadrową szkół. Na ogół dyrektor ma zniżkę godzin dydaktycznych, więc wypracowuje ich w klasie niewiele. Jeśli jest nauczycielem nauczania początkowego, będzie to istotnie mniej godzin niż przewiduje plan nauczania. Konsekwencją tej sytuacji jest konieczność realizacji zajęć przez jeszcze jedną osobę. Jak widać uwarunkowania instytucjonalne, a nie dobro dziecka, wyznaczają ramy organizacyjne jego funkcjonowania w szkole.

Sekwencja zdarzeń 2. Studentka prosi o pilne spotkanie. Stało się coś strasznego - wyjaśnia - dzieci otrzymały jedno niepoprawne zadanie do rozwiazania. Zdaniem nauczycielki moja praca jest $z$ tego powodu jedna wielka

${ }^{4}$ Dane pochodzą od 37 osób, których postrzeganie wczesnej edukacji uznałam za istotne oraz 18 uczestniczących w 2 wywiadach grupowych (st. dzienne 10 osób, zaoczne 8). Dyskusje prowokowane były, m.in. prezentowanymi niżej opisami zajęć w szkole i przedszkolu.

${ }^{5}$ Ze względów etycznych podaję tylko te dane o miejscach i osobach, które są tu konieczne.

${ }^{6}$ Por. zapis „Zajęcia edukacyjne prowadzi nauczyciel (nauczyciele)...” w rozporządzeniu Ministra Edukacji Narodowej i Sportu z dnia 26 lutego 2002 r. w sprawie podstawy programowej wychowania przedszkolnego oraz ksztatcenia ogólnego w poszczególnych typach szkót (Dz. U. $\mathrm{Nr} 51$, poz. 458, z późn. zm).

${ }^{7}$ Por. „Zalecane warunki i sposób realizacji (pkt 6) w rozporządzeniu Ministra Edukacji Narodowej z dnia 23 grudnia 2008 r. w sprawie podstawy programowej wychowania przedszkolnego oraz ksztatcenia ogólnego w poszczególnych typach szkót (Dz. U. z 2009 r. Nr 4, poz. 17). 
kompromitacja. Okazuje się, że przygotowując zadania testu matematycznego dla trzecioklasistów ${ }^{8}$ studentka pomyłkowo wpisała w miejsce cyfry 9 , cyfrę 6 , więc rozwiązanie $(63 / 6=10,5)$ wymagało ponadprogramowych umiejętności. Uczniowie $\mathrm{w}$ większości poradzili sobie stosując własne prowadzące do rozwiązania strategie, albo poprawiając we właściwy sposób zauważony błąd (przeprawiając cyfrę 6 na 9). Studentka była zachwycona, że zadanie dostarczyło cennych informacji o sposobach matematycznego myślenia badanych dziewięciolatków. Nauczycielka natomiast zignorowała okazję do rozpoznania oraz analizy strategii uczniów, gdy nie mają oni możliwości mechanicznego powielania znanego toku postępowania. Skupiła się na tym, czy test jest poprawny, czy też nie. Jednocześnie znacznie więcej uwagi oraz aktywności poświęciła samej studentce, którą oceniała z pozycji „nadzorującej władzy”.

Przykład powyższy dobrze wpisuje się w obraz nauczyciela edukacji wczesnoszkolnej prezentowany przez badaczy, tj. obraz osoby myślącej schematycznie. Jak m.in. konkluduje Iwona Czaja-Chudyba, ta grupa nauczycielek, jawi sie jako spoteczność preferujaca wysoce sformalizowane procedury nauczania oraz jako osoby niesamodzielne i nieaktywne intelektualnie ${ }^{9}$. Ponadto, autorka wskazuje ich niski poziom myślenia pytajnego oraz trudności w stawianiu pytań. I nie chodzi tu jedynie o pytania kierowane do uczniów, ale także o problematyzowanie otaczającej rzeczywistości. Jak podkreśla I. Czaja-Chudyba, nawet te nauczycielki, które potrafia zwerbalizować pytania dotyczqce praktyki pedagogicznej, nie podejmuja aktywności, aby cokolwiek zbadać w tym zakresie samodzielnie $e^{10}$. Zastanawiając się, co mogło spowodować brak zaciekawienia ww. nauczycielki myśleniem dzieci, warto przywołać analizy Doroty Klus-Stańskiej i Marzenny Nowickiej ${ }^{11}$. Autorki podkreślają, że w szkole dominuje orientacja na wynik ${ }^{12}$, a nie na aktywność intelektualną dziecka. Konsekwencją takiego rozumienia celów kształcenia jest dążenie do zaznajomienia uczniów z technikami obliczeniowymi i ich ćwiczenie - utrwalenie w typowych sytuacjach ${ }^{13}$. Być może dlatego samodzielne dochodzenie dziecka do rozwiązania zadania, szczególnie w sytuacjach nietypowych, pozostaje poza zainteresowaniem nauczycielek. W ich bowiem przekonaniu nie prowadzi do ww. celu, którym jest wyuczenie kolejnych czynności i uzyskanie wyniku.

${ }^{8}$ Test pochodził z: M. Dąbrowski, M. Żytko, Badanie umiejętności podstawowych uczniów trzecich klas szkoły podstawowej. Raport z badania ilościowego, Warszawa 2007.

${ }^{9}$ I. Czaja-Chudyba, Jak $i$ o co pyta nauczyciel? - determinanty ciekawości poznawczej $i$ postawy badawczej w edukacji, [w:] A. Czajkowska, W. Otwinowski (red.), Edukacyjne zagrożenia i wyzwania młodego pokolenia, t.3, Poznań 2009, s. 196.

${ }^{10}$ Tamże, s. 195.

${ }^{11}$ D. Klus-Stańska, M. Nowicka, Sensy i bezsensy edukacji wczesnoszkolnej, Warszawa 2005, s. 105-180.

${ }^{12}$ Tamże, s. 110.

${ }^{13}$ Tamże. 
Relacje z przebiegu zajęć. Studentka przedstawia szczegółowe obserwacje z tygodniowego przebiegu 15 jednostek zajęciowych w klasie III szkoły podstawowej. Każda stanowi odrębny przedmiot (np. matematyka, język polski) i określona jest jako „lekcja” oraz trwa 45 min. Prawie każda ma też podobny tok. Rozpoczyna się przepytywaniem $\mathrm{z}$ materiału, który był realizowany poprzednio, bez względu na związek z bieżącą tematyką. Następnie nauczycielka czyta tekst lub podaje nowe treści. Końcowa część jest pracą z podręcznikiem.

Relacja 1. (fragment). Temat „Woda w naszym życiu”. Zaczyna się przepytywaniem z czytania wierszy „Tańce polskie”, o których była mowa poprzedniego dnia (...) Dalej nauczycielka czyta nowy wiersz „Odkręcam kran”, opowiada o wartości wody i obiegu wody w przyrodzie. Dzieci ogladaja ilustrację z przetwarzaniem wody $w$ gospodarstwie domowym i rozmawiaja o tym, $w$ jakich sytuacjach woda jest potrzebna $w$ domu. Potem indywidualnie wykonuja zadanie w zeszytach ćwiczeń polegajace na porzqdkowaniu zdań.

Relacja 2. (fragment). Uczniowie maja możliwość wyboru jednego wiersza i przeczytania na ocenę. Marysia (...) otrzymata piatkę. Robert jest smutny. Wybiera najtrudniejszy wiersz i ma duże problemy żeby go przeczytać. Nauczycielka nie stawia oceny i mówi: „czytaj więcej $i$ wtedy będzie dobrze”.

Zwraca uwagę niezgodnie $\mathrm{z}$ wymogami, podejście do nauczania i oceniania. We wszystkich 15 . sytuacjach występuje ocenianie z zastosowaniem systemu cyfrowego. Poza stopniami szkolnymi informacje zwrotne ograniczają się do stwierdzeń dobrze, źle, choć są też zachęty do podejmowania wysiłku. Ponadto, $\mathrm{w}$ całym tygodniu edukacja przyrodnicza pojawia się wyłącznie $\mathrm{w}$ formie werbalnej i papierowej ${ }^{14}$.

Obserwująca zajęcia nie zwróciła uwagi na wskazywane wyżej kwestie, poddałam je więc pod dyskusję. Co do sposobu oceniania, studentki jednogłośnie podkreślały, że uprawniona jest wyłącznie ocena opisowa, co regulują odpowiednie przepisy ${ }^{15}$. Jednocześnie krytykowały obowiązujący system. Tłumaczyły, że stopień szkolny motywuje i więcej „mówi” uczniowi i jego rodzicom. Jak wynika $\mathrm{z}$ badań prezentowanych przez Małgorzatę Żytko, podejście to jest spójne z dominującym wśród nauczycieli podglądem, że ocena opisowa nie mobilizuje dzieci do wysitku edukacyjnego ${ }^{16}$. Nauczyciele podkreślają konieczność powrotu do cyfrowej formy oceniania uczniów ${ }^{17}$. Traktują ocenianie opisowe jako „obce” i w dodatku kłopotliwe zadanie. Realizuja je, gdy

${ }^{14}$ Jak w Relacji 1.

${ }^{15}$ Rozporzadzenie Ministra Edukacji Narodowej z dnia 30 kwietnia 2007 r. w sprawie warunków i sposobu oceniania,, klasyfikowania i promowania uczniów i stuchaczy oraz przeprowadzania sprawdzianów i egzaminów w szkołach publicznych (Dz. U. Nr 83, poz. 562, z późn. zm.).

${ }^{16}$ M. Żytko, Ocenianie opisowe, [w:] Encyklopedia pedagogiczna XXI wieku,. t. 3, pod red. T. Pilch, Warszawa 2004, s. 730.

${ }^{17}$ Tamże. 
ze względów formalnych nie ma już innego wyjścia. Na co dzień posługują się łatwiejszym i bardziej w ich przekonaniu czytelnym dla dzieci oraz rodziców stopniem szkolnym ${ }^{18}$ lub umownym znakiem. Ten odbiór oceniania opisowego jako czegoś zewnętrznego, jest $\mathrm{w}$ pełni zrozumiały. Aby z zaangażowaniem podejmować jakieś działanie, a szczególnie to wymagające dodatkowego przygotowania i wysiłku, trzeba widzieć w tym sens, też dla siebie. Prawdopodobnie brak jeszcze rozumienia, że nie chodzi tu o samą formę oceny, ale w ogóle o zmianę podejścia dydaktyczno-wychowawczego do kształcenia i poznawania uczniów. Wynika to $\mathrm{z}$ pewnej inercji funkcjonowania nauczyciela w obowiązującym przez wiele lat paradygmacie dydaktyczno-wychowawczym, w którym procesy edukacyjne rozumiane były zerojedynkowo i dominowało podejście nastawione na mierzalne efekty procesu uczenia się $\mathrm{i}$ ich porównywalność. Jak pisze Anna Sajdak, w modelu tym nie ma miejsca na indywidualizowanie drogi rozwojowej ucznia. (...) Przedmiotem oceny staje się to, co dzieci potrafia reprodukować z przedstawionej im wcześniej zewnętrznej rzeczywisto$\dot{s} c i^{19}$. Ponieważ ocenia się osiagnięcia $\mathrm{w}$ stosunku do ściśle określonego, pożądanego społecznie standardu, to ich rangowanie w formie stopni szkolnych wystarcza do stwierdzenia na ile standard ten jest spełniany.

Poprosiłam też studentki o ogólną ocenę zajęć i przeanalizowanie, na ile rozwijają one zdolności poznawcze uczniów. Uznały, że wszystkie są bardzo typowe i nieciekawe (wydaja mi się nudne $i$ mało atrakcyjne, stresujace i nie wyróżniaja się). Jedynym rozwiązaniem dydaktycznym określonym jako dość interesujace było odtworzenie muzyki Chopina podczas czytania przez nauczycielkę wiersza „Żelazowa Wola” (dzieci jednocześnie śledziły jego treść w podręczniku). Podałam co prawda w watpliwość, czy jednoczesne słuchanie czytania, muzyki i ciche czytanie sprzyja poznawaniu. Argumentowały, że mogło to być korzystne ponieważ $w$ klasie III dzieci już dobrze radza sobie z czytaniem oraz to mogło być dobre dla dziecka, gdyż wptywato na wiele zmystów.

Bardzo krytycznie ocenione zostały zajęcia dotyczące obiegu wody w przyrodzie i jej znaczenia (cyt: zapoznanie dzieci $z$ tematyka wody za pomoca wiersza?). Niestety nie jest to przykład jednostkowy. Choć zgadzamy się co do tego, że najbardziej zajmujaca i potencjalnie korzystna edukacja przyrodnicza i naukowa wywodzi się $z$ naturalnej dziecięcej ciekawości ${ }^{20}$ - to uczniowie w naszych szkołach raczej tej ciekawości nie zaspokoja, bo nie badają świata, nie eksperymentują, a i nie mają wielu okazji zdziwić się rozmaitymi zjawiska-

${ }^{18}$ M. Ganczarek, Nowa koncepcja oceny ucznia w szkole, [w:] Z. Ratajek, M. Kwaśniewska (red.), Edukacja elementarna w zreformowanym systemie szkolnym, t. 2, Kielce 2004, s. 258.

${ }^{19}$ A. Sajdak, Edukacja kreatywna, Kraków 2008, s. 67.

${ }^{20}$ G. Hardy, Co to znaczy być nauczycielem przyrodoznawstwa, [w:] S. Dylak (red.), Przyroda. Badania. Język. Przyrodnicze rozumowanie i komunikowanie się najmłodszych, Warszawa 1997, s. 34. 
$\mathrm{mi}^{21}$. Aktywność dzieci - podobnie jak w wyżej wymienionych przykładach polega głównie na słuchaniu, czytaniu tekstów, rozwiązywaniu zadań według ściśle określonego wzoru. Potwierdzają to wykorzystywane przez nauczycieli podręczniki i zeszyty ćwiczeń. Z rzadka pojawiają się $w$ nich zadania lub polecenia wymagające działania na obiektach przyrody (np. eksperymentowania), czy obserwacji. Jest to sytuacja ze wszech miar niekorzystna. Przyswojenie pojęcia, czy opanowanie zasady - jak podkreślają Mick Dunne i Stanisław Dylak - powinno być efektem praktycznej działalności uczniów, uruchamianej poprzez zadania ${ }^{22}$. Zwracają uwagę, że w kształceniu przyrodniczym na poziomie elementarnym ważne jest:

- rozwiązywanie problemów (rekonstruowanie struktur o niepełnych danych, które wymaga wykorzystania uprzedniej wiedzy: pojęć i zasad) ${ }^{23}$,

- opanowanie umiejętności percepcyjno-motorycznych (dokonywanie pomiarów, wykonywanie rysunków, map, posługiwanie się prostą aparaturą, itp.),

- postugiwanie się różnymi formami ekspresji jako środkiem kształtowania umiejętności formułowania i prezentacji własnych myśli, wrażeń i przeżyćc ${ }^{24}$.

Dopełnię ten obraz przykładem badań sondażowych na temat roli zabawy badawczej $\mathrm{w}$ kształtowaniu pojęć przyrodniczych $\mathrm{w}$ przedszkolu i klasie I szkoły podstawowej. Były one prowadzone na terenie jednej z dzielnic Warszawy wśród 70 nauczycielek wychowania przedszkolnego i nauczania początkowego w 2009 roku. Powodem, dla którego studentka podjęła temat, było przekonanie, że edukacja przyrodnicza w szkole podstawowej jest zaniedbywana, a zajęcia $\mathrm{z}$ tego zakresu nie są realizowane w sposób aktywizujący myślenie naukowe dzieci. Przyczyną może być zdominowanie kształcenia w klasie I ćwiczeniem czytania i pisania oraz niedocenianie znaczenia zabawowej aktywności dzieci. W mojej ocenie wynika to $\mathrm{z}$ niedostatku wiedzy i umiejętności. Badane przez studentkę nauczycielki co prawda uważają, iż zabawa badawcza (eksperymentowanie) wpływa korzystnie na rozwój poznawczy dziecka, ale jako formę wykorzystywaną w pracy dydaktycznej w klasie I, wymieniło ją tylko $14 \%$ z nich. Nie dziwi więc, że prawie połowa (46\%) miała wątpliwości, czy dzieci poprzez zabawy badawcze poszerzyły swoją wiedzę o otaczającym je świecie. Przy czym, aż 80\% nauczycielek wskazywało, że nie posiada odpowiedniego przygotowania zawodowego do prowadzenia aktywności badawczej z dziećmi. Tyle samo uznało, iż główną przeszkodę stanowią nieodpowiednie

${ }^{21}$ E. Arciszewska, Pedagogiczne mechanizmy ograniczania predyspozycji poznawczych dziecka, [w:] J. Łaszczyk, M. Jabłonowska (red.), Zdolności i twórczość jako perspektywa wspótczesnej edukacji, Warszawa 2009, s. 14.

${ }^{22}$ M. Dunne, S. Dylak, Planowanie zajęć z edukacji przyrodoznawczej, [w:] S. Dylak (red.), Przyroda. Badania. Język. Przyrodnicze rozumowanie $i$ komunikowanie sie najmłodszych, Warszawa 1997, s. 16.

\footnotetext{
${ }^{23}$ Tamże.

${ }^{24}$ Tamże, s. 17.
} 
warunki organizacyjne szkoły, co każe myśleć, że brak orientacji na czym ma polegać działalność badawcza dziecka. Przecież większość sytuacji aktywizujących myślenie najmłodszych na temat otaczającej rzeczywistości nie wymaga skomplikowanych technicznie warunków (obserwowanie roślin, przedmiotów w różnych warunkach, itp.).

Jednocześnie ponad $90 \%$ respondentek skarżyło się, że nie otrzymuje w tym zakresie żadnego wsparcia merytorycznego. Odpowiedzialnością za ten stan rzeczy nie można obciążyć samych nauczycielek. Wydaje się bowiem, że ani one, ani ich środowisko doradcze nie posiadają odpowiednich kompetencji z powodów bardziej ogólnych. Są to zaszłości naszego funkcjonowania w modelu transmisyjnym, w którym wiedza o świecie była traktowana i podawana jako gotowa oraz zamknięta. $Z$ tego modelu wyrosło niezasadne przekonanie, że można i trzeba nauczyć dziecko poprzez odpowiedni przekaz, a jego wiedza intuicyjna jest czymś do wykorzenienia a nie do użycia w procesie kształcenia. Jak przekonywałam już w innym miejscu wciąż niestety traktuje się umysł jak statyczny „bank” porcji informacji, do których można dołożyć (usunąć) następne dane - jak w puzzlach - i nie zmieni to jakościowo danych uprzednich ${ }^{25}$. Stąd myślenie nauczycielskie przywoływane też przez D. Klus-Stańską jak uczniowi dobrze wyttumacze, to on (...) posiadzie wiedze $e^{26}$. Jest to jedna $\mathrm{z}$ głównych barier ograniczania aktywności badawczej w szkole. $\mathrm{W}$ tym podejściu bowiem samodzielne odkrywanie i związane z nim błędne rozumowanie w toku dochodzenia do kompetencji może być przez nauczyciela uważane za stratę czasu, a w niektórych przypadkach wręcz za niekorzystne zakłócenie procesu dydaktycznego.

W tym kontekście warto przywołać również niektóre wnioski z badań studentki, która na przełomie 2008-2009 r. śladem Renaty Reclik ${ }^{27}$ analizowała zadania domowe uczniów pod kątem spełniania przez nie postulatu podmiotowości. Dokonała przeglądu oferty wydawniczej przeznaczonej do klasy II szkoły podstawowej (22 podręczników, zeszytów ćwiczeń i kart pracy) i przykładów zadanych dzieciom prac domowych (99 zadań z zakresu edukacji polonistycznej, matematycznej oraz przyrodniczej). Niestety wyniki tych badań nie napawają optymizmem. Wiodącym źródłem prac domowych jest oferta, w której zestawy zadań i poleceń, rzadko:

- umożliwiają nauczycielowi dopasowanie ich do potrzeb, zainteresowań i możliwości dziecka,

${ }^{25}$ E. Arciszewska, Wiedza potoczna w procesie konstruowania znaczeń, [w:] A. Hibszer (red.), Polska dydaktyka geografii. Idee - Tradycje - Wyzwania, Sosnowiec 2008, s. 80.

${ }^{26}$ D. Klus-Stańska, Edukacja elementarna a rozwój kompetencji poznawczych dzieci, [w:], K. Lubomirska (red.) Edukacja elementarna. Podstawy teoretyczne - wybrane zagadnienia, Warszawa 2005, s. 29.

${ }^{27}$ R. Reclik, Uczniowskie zadania domowe w kontekście podmiotowości, [w:] P. Waśko, M. Wrońska, A. Zduniak (red.), Polski system edukacji po reformie 1999 r. Stan. Perspektywy. Zagrożenia, t. 1, Warszawa-Poznań 2005, s. 97-103. 
- pozwalają dziecku na wybór, planowanie i współtworzenie zadań domowych,

- pobudzają aktywność twórczą.

Jednocześnie, nauczyciele traktują prace domowe instrumentalnie, tj. jako narzędzie służące przede wszystkim zapamiętywaniu i utrwaleniu treści oraz wyćwiczeniu umiejętności wynikających z programu kształcenia. Nawet, gdy proponują dzieciom wykonanie zadania wg własnego pomysłu (typowe jest np. ułożenie kilku zdań z podanymi wyrazami), to brakuje takich, które rozwijałyby samodzielne myślenie i działanie w różnych sytuacjach. Najczęściej dzieci wykonuja $w$ zeszytach przedmiotowych prace pisemne (układanie zdań, wypełnianie luk, przepisywanie tekstu, itp.) Pojawiło się zaledwie kilka przykładów, które sprzyjały twórczej aktywności uczniów oraz samodzielnemu dochodzeniu do wiedzy. Sporadycznie wystapiły zadania artystyczne lub techniczne, albo polegające na wyszukiwaniu informacji w różnych źródłach. Wśród wszystkich analizowanych zadań pojawiły się tylko pojedyncze polecenia dokonania obserwacji i wcale nie wystapiło zachęcenie do eksperymentowania. Wyniki tych badań potwierdzają, że edukacja przyrodnicza jest ,papierowa”. To „gadanie" o rzeczywistości a nie jej badanie ${ }^{28}$.

\section{Relacje i interpretacje - wychowanie przedszkolne}

Eksperymentowanie. Szczęśliwie nieco bardziej optymistycznie można ocenić ten obszar edukacyjny w placówkach przedszkolnych. Z opisywanych już wyżej badań wynika, iż co prawda niewiele ponad $17 \%$ nauczycielek przedszkoli często wykorzystuje zabawę badawczą i eksperymentuje $\mathrm{z}$ dziećmi, ale jednocześnie większość z nich (74\%) deklaruje stosowanie innych, ważnych dla poznawania świata przyrody form zabawowych. Nie mają ponadto wątpliwości co do tego, że poprzez zabawy badawcze przedszkolaki poszerzyły swoją wiedzę. Takie przekonanie miało $86 \%$ nauczycielek. Podkreślały (77\%), że w edukacji przyrodniczej aktywność badawcza i dziecięce eksperymentowanie zajmuje bardzo ważne miejsce (w przypadku nauczycielek klasy I było to $37 \%$ ), a tylko kilka (6\%) stwierdziło, że aktywność ta jest mało istotna lub nieistotna (nauczycielki klasy I - 17\%). I wreszcie, więcej nauczycielek przedszkoli $(89 \%)$ niż klasy I (63\%) zaobserwowało, że eksperyment przyrodniczy zwiększył zainteresowane dzieci jakimś problemem, czy zjawiskiem przyrodniczym. Przy czym, aż 74\% nauczycielek wskazywało, że nie posiada odpowiedniego przygotowania do organizowania aktywności badawczej dzieci. Ponad połowa (54\%) uznała, iż placówki nie są do tego odpowiednio przygotowane. Odczucie braku wsparcia merytorycznego ma aż $74 \%$ badanych nauczycielek przedszkoli.

\footnotetext{
${ }^{28}$ E. Arciszewska, Badanie czy gadanie, „Edukacja i Dialog” 2000, nr 3 (116).
} 
Problem niewystarczającego przygotowania i doskonalenia zawodowego nauczycieli wczesnej edukacji dotyczy wielu obszarów i nasila się, mimo że jest to grupa chyba bardziej aktywna samokształceniowo niż inne. Szczególnie paląca jest potrzeba uaktualnienia bądź uzupełnienia wiedzy psychologicznej nauczycieli i jej aplikacja na poziom praktycznego działania. Dla prowadzenia kształcenia, jak podkreśla Ewa Szadzińska ${ }^{29}$, będzie to przede wszystkim wiedza o aktywności poznawczej i psychologicznych prawidłowościach uczenia się. Nauczyciel - pisze autorka - musi posiadać duży zasób wiedzy (teoretycznej), by ustalić dziatanie, które jest etapem rozwiazania problemu ${ }^{30}$. Można te wnioski i postulaty odnieść także do sfery wychowawczej. O tym, że w wielu przypadkach nauczyciele nie posiadaja żadnej wiedzy, m.in. o źródłach trudności w zachowaniu dziecka, pisze Anna Bajorek w kontekście badań własnych dotyczących ich roli we wspomaganiu dziecka w wieku przedszkolnym ${ }^{31}$.

Trudne zachowania trzylatków. Zanalizujemy z tej perspektywy przykłady trzech $\mathrm{z}$ dziesięciu obserwacji odnotowanych przez studentkę. W ciagu sześciu miesięcy 2009 r. starała się obserwować w swoim przedszkolu dzieci trzyletnie i ich wychowawczynie w sytuacjach, które uznała za trudne wychowawczo. Istotną część jej analiz stanowiły też wypowiedzi nauczycielek na temat przyczyn agresywnych zachowań dzieci.

Sytuacja 1. Dziewczynka (2,5 roku) rzuca wtasna maskotka, wktada do buzi, bije ja. Nauczycielka mówi: „Proszę nie rób tego, nie wolno rzucać zabawkami. Jak nie postuchasz, zabiorę ci ja." Dziewczynka nie reaguje. Nauczycielka: „Nie postuchataś - zabiera zabawkę - oddam później”. Dziewczynka krzyczy, gryzie siebie, tupie, bije inne dziecko. Nauczycielka sadza ja na „karnym krzesetku”, mówiqc: „Porozmawiam z toba, gdy się uspokoisz i zastanowisz nad swoim zachowaniem". Dziewczynka przez ok. 80 min. powtarza imie maskotki „Panterka”, tupie, krzyczy. Nauczycielka ignoruje to zachowanie. Wreszcie zadaje pytanie, „Dlaczego rzucasz zabawkq?”, dziewczynka milczy, a następnie obiecuje: „Więcej nie będę”.

Sytuacja 2. Pora leżakowania. Chłopiec (3 lata i 2 miesiace) rzuca poduszkq, kołdrq i chowa się pod leżak. Nauczycielka: „Zbierz rzeczy i połóż się na leżak - i pyta - chcesz spać?” Chtopiec: „Chce spać” - powtarza kilkakrotnie i zbiera rzeczy. Po kilku minutach sytuacja sie powtarza. Nauczycielka sadza dziecko na „karnym krzesetku” przy stoliku. Dziecko uderza $w$ stolik $i$ krzesta, pluje, huśta się na krzesetku i ucieka z miejsca ok. 20 razy. Nauczycielka za

${ }^{29}$ E. Szadzińska, Zróżnicowanie wiedzy o procesie ksztatcenia jako podstawy działań nauczyciela klas I-III $i$ wychowawcy przedszkola, [w:] E. I. Laska (red.), Nauczyciel wobec wczesnej edukacji dzieci, Rzeszów 2007, s. 169.

${ }^{30}$ Tamże.

${ }^{31}$ A. Bajorek, Rola nauczyciela we wspomaganiu rozwoju dziecka $w$ wieku przedszkolnym, [w:] E. I. Laska (red.), Nauczyciel wobec wczesnej edukacji dzieci, Rzeszów 2007, s. 65. 
każde przewinienie przedtuża karę. Trwa to ok. dwóch godzin. Pod koniec tej sytuacji nauczycielka pyta: „Dlaczego tak się zachowujesz?” Dziecko milczy.

Sytuacja 3. Sprzqtanie zabawek. Dziewczynka (2 lata i 9 miesięcy) ugryzła chłopca w ucho, po czym zaczęta krzyczeć i płakać. Za kare została posadzona na „karnym krzesetku” na 5 minut. Siedzac powtarzata:, To jego wina, to jego wina”. Kara została przedtużona do 20 min., tj. do momentu, gdy dziewczynka przyznała się, że to ona ugryzła chłopca. Na pytanie nauczycielki: „Dlaczego to zrobitaś?" dziecko wyjaśnito, że chciato samo odsunać szuflade $i$ schować na miejsce zabawke, ale chłopczyk ja wyprzedzit w tej czynności.

Pierwsza, robocza wersja wszystkich dziesięciu relacji nie zwierała żadnych szczegółowych opisów dotyczących tego na czym polegało ukaranie dziecka i jak długo kara obowiązywała. Występowały wyłącznie sformułowania: nauczycielka data karę, otrzymat karę. Studentka była zaskoczona moim dociekaniem w tej sprawie - postępowanie wychowawcze nauczycielek wydawało się jej oczywiste. Jednocześnie nie zauważyła, że w wyniku skomasowania tych 10. zdarzeń krytycznych powstał obraz przedszkola bezradnego wobec agresywności dzieci i szkodliwego wychowawczo. To, co zastanawia, to brak zastosowania jakichkolwiek innych poza „karnym krzesełkiem” sposobów regulacji zachowania dzieci. Kara ta była przedłużana w nieskończoność, mimo że wiadomo, iż karanie jest jednym z najmniej skutecznych sposobów modyfikowania zachowania. Przy czym, nie wystapiło tak potrzebne nagradzanie. Dowodzi to niestety, że nauczycielki, albo nie posiadają, albo nie potrafią zastosować w praktyce wiedzy o metodach wychowania, do których należy m.in. nagradzanie i karanie. Wywiady potwierdziły również, że stan ich wiedzy na temat przyczyn agresji u dzieci trzyletnich jest ograniczony. Jako źródło wszystkich zachowań tego typu podawały środowisko rodzinne (powielanie wzorców, przyzwolenie na agresję). Zupełnie nie brały pod uwagę uwarunkowań psychologicznych wynikających z kształtowania się osobowości dziecka w okresie, który charakteryzuje negatywizm, upór, krnąbrność i samowola ${ }^{32}$. $\mathrm{Z}$ wywiadu $\mathrm{z}$ tymi nauczycielkami, ale także $\mathrm{z}$ moich rozmów ze studentką wynika też niedostatek wiedzy o formach agresji, co być może spowodowało nieadekwatne do sytuacji reakcje na zachowania dzieci. Każdą agresję dziecka nauczycielki i studentka intuicyjne klasyfikowały jako wrogą. Nic niestety badanym nie było wiadomo o agresji instrumentalnej, choć częściej niż wroga pojawia się u trzylatków ${ }^{33}$.

Poddałam opisane wyżej przykłady pod dyskusję w dwóch grupach studentek. Wśród możliwych przyczyn agresji dzieci, wymieniały one, podobnie jak

${ }^{32}$ L. S. Wygotski, Kryzys trzeciego roku życia, [w:] A. Brzezińska, M. Marchew (red.), Lew S. Wygotski. Wybrane prace psychologiczne II. Dzieciństwo i dorastanie, Poznań 2002, s. 131-140.

${ }^{33}$ M. Kielar-Turska, Średnie dzieciństwo. Wiek przedszkolny, [w:] B. Harwas-Napierała, J. Trempała (red.), Psychologia rozwoju człowieka. Charakterystyka okresów życia, t. 2, Warszawa 2008, s. 107. 
nauczycielki, przede wszystkim sytuację w rodzinie. Poza tym, skupiały się wyłącznie na bezpośrednich przyczynach nieakceptowanego zachowania dzieci. Wskazywały cyt. przykre doświadczenia dziecka $\mathrm{z}$ danego dnia, potrzebe wytadowywania agresji i złości, niewiedzę dzieci: prawdopodobnie nie wiedziaty jak mogq odreagować swoje zachowanie, to że reakcje dzieci były kontrreakcjami na agresję rówieśników.

Studentki zostały też poproszone o skomentowanie reakcji nauczycielek. Krytycznie oceniły fakt, że w każdym przypadku dzieci sadzane były na „karnym krzesełku” oraz zwróciły uwagę, że kary były zbyt długie. Nie umiały natomiast uzasadnić dlaczego to zachowanie nie było właściwe. Argument, że cyt. nauczycielki nie staraty się zrozumieć dziecka, nie uwzględnia odpowiedzi na pytanie, o to dlaczego powinny je rozumieć. Jednocześnie pojawiały się pozytywne oceny $\mathrm{z}$ sensownym uzasadnieniem, cyt: nauczycielka postapiła stusznie, ponieważ najpierw ostrzegła dziecko przed konsekwencjami, a gdy ono nie postuchało dała karę. Były one pojedyncze i nie spotkały się $\mathrm{z}$ aprobata pozostałych studentek uczestniczących $\mathrm{w}$ dyskusji. Zewnętrzny ogląd tych sytuacji pozwolił badanym na spostrzeżenie, że „coś jest nie tak” - niewątpliwie wystapiła świadomość, że proces wychowawczy w przedszkolu był nieprawidłowy i powinien przebiegać zupełnie inaczej. Wobec widocznych trudności w zwerbalizowaniu sądów, trudno określić jednak, czy trafne oceny sytuacji wychowawczych wynikały z wiedzy, czy też raczej z intuicji.

Swoboda w aktywności plastycznej przedszkolaków. Wobec problemów wychowawczych, z którymi stykają się nauczycielki przedszkoli, zagadnienia dotyczące organizacji zajęć plastycznych mogą wydawać nie tylko śmiesznie proste, ale też mało istotne. Chyba tak jednak nie jest skoro w najnowszej podstawie programowej wskazano aż trzy obszary wychowania przez sztukę w przedszkolu: dziecko widzem i aktorem, muzyka, śpiew, plasy i taniec, oraz różne formy plastyczne $e^{34}$. Chodzi o to - uzasadnia Edyta Gruszczyk-Kolczyńska, koordynator tego projektu ${ }^{35}$ - aby autorzy programów autorskich nie pominęli żadnej $z$ tych ważnych dziedzin wychowania przez sztuke ${ }^{36} \mathrm{w}$ okresie szczególnym dla kształtowania wrażliwości estetycznej dzieci. Dalej wyjaśnia przede wszystkim dlaczego $\mathrm{w}$ podstawie programowej podkreśla się potrzebę wprowadzania dzieci w wartości estetyczne malarstwa, rzeźby i architektury, w tym architektury wnętrz, co jak pamiętamy było szeroko komentowane przez opinię publiczną. Na ksztattowanie potrzeb estetycznych dzieci - czytamy w komentarzu - wielki wptyw ma otoczenie, z jakim się stykaja. Niestety, wiele dzieci wychowu-

\footnotetext{
${ }^{34}$ Por. załącznik nr 1 do rozporzqdzenia z. 2008 r.w sprawie podstawy programowej... (Dz. U. z 2009 r. Nr 4 poz. 17).

${ }^{35} \mathrm{Z}$ ramienia MEN.

${ }^{36}$ E. Gruszczyk-Kolczyńska, Komentarz do podstawy programowej wychowania przedszkolnego, [w:] Podstawa programowa z komentarzami. Edukacja przedszkolna i wczesnoszkolna, t. 1, Warszawa 2009, s. 31.
} 
je się $w$ otoczeniu brzydkich blokowisk $i$ zniszczonej zieleni, widzi pomazane sprayem ściany domów, itp. Dlatego (...) trzeba dażyć chociażby do zrównoważenia tych niedobrych wzorców ${ }^{37}$. To co zwraca uwagę, to koncentrowanie się w wychowaniu przez sztukę na kształtowaniu preferencji i doznawaniu przyjemności przebywania w pięknym otoczeniu, a także wprowadzanie ładu wszędzie tam, gdzie dziecko się znajduje ${ }^{38}$. Pozostaje mieć nadzieję, że nauczycielki przedszkoli nie potraktują zapisów nowej podstawy programowej zbyt instrumentalnie i będą próbowały umożliwiać dzieciom ekspresję spostrzeżeń, przeżyć, uczuć w różnych formach działalności, z zastosowaniem werbalnych i niewerbalnych środków wyrazu oraz wspierać będą ich działania twórcze w różnych dziedzinach aktywności ${ }^{39}$. Choć ze spostrzeżeń badanych można wnioskować, że i dotąd nie były to dla nauczycielek łatwe do zrozumienia, a w konsekwencji do wykonania, zadania. Przebieg procesu edukacyjnego obserwowany na praktykach, w odczuciu studentek zdominowany jest, nie tylko zresztą w zakresie edukacji plastycznej, instrumentalizmem metodycznym i mechanizacją czynności dziecka ${ }^{40}$. Powszechne jest np. wypełnianie przez dzieci rozmaitych konturów kredkami, farbami, krepiną, czy innym materiałem, mimo że trudno to uznać za bardziej kształcące i rozwijające niż swobodne (tj. bez narzucania i sugerowania formy oraz obrazu) wypowiadanie się dziecka w różnych technikach plastycznych ${ }^{41}$. Przywołam tu badania sondażowe prowadzone przez jedną ze studentek na terenie warszawskiej dzielnicy Białołęka w 2009 r., w których uczestniczyło 50 nauczycielek przedszkoli publicznych $(68 \% \mathrm{z} \mathrm{za-}$ trudnionych $w$ tych przedszkolach). Celem było m.in. rozpoznanie jakie postawy wynikają z nauczycielskich deklaracji i opinii dotyczących aktywności plastycznej dzieci w przedszkolu. Przede wszystkim nauczycielki deklarowały, że korzystają w swej pracy z gotowych materiałów dydaktycznych (60\%), i oceniły je jako sprzyjające aktywności własnej i swobodzie twórczej dzieci. Jednocześnie, aż 84\% dostarcza konkretne wzory (np. szablony, rysunki do kolorowania, wycinania, sklejania, karty graficzne) do odtwarzania oraz narzuca tematykę. Nauczycielki wyjaśniały, że dzieci wolą wykonywać prace o precyzyjnie określonym temacie oraz według wzoru, ponieważ, cyt.: czasami nie maja pomystu, nie wiedzq co maja zrobić, narysować, nie maja dostatecznej wiedzy o danej technice plastycznej, bqdź maja zaburzonq samoocenę, sq ograniczone $w$ jakichś ramach i czuja się wtedy bezpiecznie, poruszaja się $w$ określonym

${ }^{37}$ Tamże.

${ }^{38}$ Tamże.

39 Takie zadania przypisywała nauczycielowi poprzednia podstawa programowa (Dz. U. z 2002 r. Nr 51, poz. 458, z późn. zm.).

${ }^{40}$ D. Klus-Stańska, Edukacja elementarna..., s. 32.

${ }^{41}$ E. Ćwieluch, Twórczość plastyczna jako czynnik wszechstronnego rozwoju dziecka 6-letniego, [w:] Z. Ratajek, M. Kwaśniewska (red.), Edukacja elementarna w zreformowanym systemie szkolnym, t. 2, Kielce 2004, s. 143. 
terytorium. Wypowiedzi te dobrze wpisują się we wnioski z badań Józefy Bałachowicz, z których wynika, że dla nauczycielek dzieci to istoty pasywne, potrzebujace parasola ochronnego przed zmierzeniem się $z$ trudna, zagrażajaca rzeczywistościq ${ }^{42}$. Z uzasadnieniami nauczycielskimi kontrastuje to, że aż $96 \%$ badanych stwierdziło, iż dzieci same chętnie podejmują inicjatywę, gdy nie są to zajęcia zorganizowane dla całej grupy. Nauczycielki wyjaśniały, że cyt. dzieci lubia wykorzystywać materiaty pozostałe po zajęciach i dowolnie je wykorzystuja - naklejaja, taczq z plastelina, uktadaja wzory, itp., gdy maja dostęp do bogato wyposażonego kacika plastycznego, lubiq tworzyć w matych zespotach lub podobnie. Trudno jest wobec tego zrozumieć, co właściwie przeszkadza w wykorzystaniu inicjatywy dzieci w programowych zajęciach przedszkolnych. Być może, podobnie jak na poziomie edukacji wczesnoszkolnej problem jest szerszej natury. Nauczyciel jest zniewolony m.in. wymienionym już instrumentalizmem metodycznym, mechanizacją czynności oraz orientacją poprawnościową i rywalizacyjnym indywidualizmem, o których jako zasadniczych barierach zmiany edukacyjnej pisze D. Klus-Stańska ${ }^{43}$. Instrumentalizm metodyczny, w jej ujęciu, to mechaniczne poddawanie się wytycznym, wskazówkom oraz wzorcom metodycznym, pochodzącym z różnych źródeł uznawanych przez nauczycieli za prawomocne. Skutkiem tego dziecko jest postacią drugoplanową. Zdalne sterowanie uczniem i nauczycielem - podkreśla D. Klus-Stańska i nie sposób z nią się nie zgodzić - uczynito jakq̨kolwiek myśl twórczq zbędna, a nawet zakłócająca. Zniewolony nauczyciel zniewala ucznia, bo jest przekonany, że ci madrzejsi od niego dobrze to zaprojektowali ${ }^{44}$. Orientacja poprawnościowa, tj. koncentracja wyłącznie na tym, aby dziecko wykonało coś lub wiedziało właściwie (zgodnie $\mathrm{z}$ zakładanym zoperacjonalizowanym celem poprawnie pisze, rysuje, odpowiada), faktycznie wyłącza edukacyjne walory samego procesu doświadczania, konstruowania wiedzy, czy tworzenia dzieła, w tym artystycznego. Instrumentalizmowi metodycznemu nauczycieli towarzyszy niestety mechanizacja czynności dziecka polegająca na nieustannym trenowaniu określonych umiejętności. W przypadku edukacji plastycznej w przedszkolu trening ten dotyczy np. sprawnego rysowania, kolorowania w ramach konturów, bez przekraczania linii brzegowej. W szkole odpowiednio do obszaru edukacyjnego, mechanizacja obejmuje czytanie, pisanie, rozwiązywanie zadań i inne umiejętności określone programem nauczania. Zachowania te D. Klus-Stańska określa „treningiem bezmyślności”, ${ }^{45}$. Jako mniej istotną barierę zmiany autorka wymienia rywalizacyjny indywidualizm, który sprowadza się do ilościowego

${ }^{42} \mathrm{~J}$. Bałachowicz, Teorie indywidualne nauczycieli klas poczatkowych-schematy i problemy zmiany, [w:] K. Żegnałek (red.), Kompetencje nauczyciela edukacji poczqtkowej, Warszawa 2008 , s. 150.

${ }^{43}$ D. Klus-Stańska, Edukacja elementarna ..., s. 32 i s. 34.

${ }^{44}$ Tamże, s. 32.

${ }^{45}$ Tamże. 
określania różnic postępów (osiagnięć) dzieci i ich porównywania za pomocą bardziej lub mniej umownej skali. Warto się do tej kwestii odnieść ze względu na przywołane wyżej sytuacje oceniania i wskazane ograniczenia swobody twórczej przedszkolaków. Porównywanie dzieci między sobą pod względem posiadanej wiedzy, umiejętności i uzdolnień, w tym plastycznych, to chyba najbardziej utrwalona i dlatego niemożliwa do wykorzenienia codzienność naszej edukacji (sukces dziecka jest obliczanq miarq nagromadzonych wiadomości, a zachęta do aktywności jest obwarowywanie lokata rankingowa: najtadniej napisat, najtadniejszy rysunek, najszybciej posprzatane $\left.{ }^{46}\right)$. Być może dlatego tak trudno nauczycielom zaakceptować i przestawić się na nowy system oceniania, który wyklucza zobiektywizowaną i rywalizacyjną porównywalność uczniów między sobą. W to miejsce wprowadza obowiązek dostrzeżenia i zakomunikowania we właściwej formie zmian w konkretnym dziecku. Wymaga to przede wszystkim umiejętności profesjonalnego poznawania każdego z osobna $\mathrm{w}$ toku procesu edukacyjnego. Nie chodzi bowiem o określenie mierzalnych i porównywalnych osiagnięć etapowych, ale o to w jaki sposób dziecko dochodzi do wiedzy oraz umiejętności.

\section{Refleksja nad interpretacjami}

Obraz wczesnej edukacji wyłaniający się z doświadczeń studentek, ich zachowań oraz werbalizowanych $w$ formie pisemnej i ustnej interpretacji, okazuje się zbieżny $\mathrm{z}$ obrazem wynikającym $\mathrm{z}$ badań pedagogicznych prowadzonych w ostatnich latach. Są one szeroko prezentowane w literaturze przedmiotu, a niektóre z nich przywołałam analizując poszczególne relacje i nadawane im sensy. W zasadzie - poza sposobami rozwiązywania (a raczej nierozwiązywania) problemów wychowawczych z maluchami - nic w tej edukacji nie zaskakuje, bez względu na perspektywę, z której dokonywana jest interpretacja. Co dziwniejsze, studentki zapytane - już po zogniskowanej na konkretnych kwestiach dyskusji - czy jest coś, co je w toku obserwacji pracy nauczycielek zachwyciło, zdenerwowało, pozytywnie lub negatywnie zaskoczyło, poza pojedynczymi wypowiedziami stwierdzały, że, cyt: wszystko jest doktadnie tak jak sobie wyobrażałam, jak się spodziewałam.

Pojawiły się niewątpliwie moje „zdziwienia”. Spodziewałam się skrajnych sądów o różnych aspektach wczesnej edukacji, od miażdżącej krytyki, po zachwyty - tego nie było. Studentki wypowiadały się ogólnikowo i powierzchownie. Świadczy to być może o bezrefleksyjności i ją chyba niestety zapowiada na przyszłość. Albo też, problem polega na tym, że zasób doświadczeń i wiedzy studentek nie jest jeszcze bogaty, a zdziwienie jak pisał Jerome Bruner,

\footnotetext{
${ }^{46}$ Tamże, s. 43.
} 
faworyzuje umysty dobrze przygotowane ${ }^{47}$. Jak obecnie postuluje myślenie o myśleniu powinno stać się zasadniczym składnikiem każdej wspomagajacej praktyki edukacyjnej ${ }^{48}$. Chodzi o aktywne eksplorowanie i analizowanie rzeczywistości i siebie samego. Do tego potrzebne są co najmniej kompetencje poznawcze i ciekawość świata.

Jak to już wyraziłam, analizując sytuacje wychowawcze w przedszkolu, zaskakujące, że nauczycielki, ale i studentki, które są już po kursie psychologii i pedagogiki, nie potrafią uruchomić wiedzy, albo jej nie posiadają. Jest to szczególnie niezrozumiałe, że dotyczy źródeł i form agresji. Problematyka ta jest stale obecna w rzeczywistości społecznej. Wydaje się, że m.in. z tych względów, wprowadzono do podstawy programowej wymóg opracowania przez każdą szkołę/placówkę dostosowanego do potrzeb rozwojowych dzieci i danego środowiska programu profilaktyki ${ }^{49}$. Abstrahując od przepisów, tematyka związana z przyczynami agresji dzieci w różnym wieku i sposobami jej zapobiegania pojawia się w mediach, placówkach oświatowych (np. doskonalenia nauczycieli) i z pewnością w systemie wewnątrzszkolnego doskonalenia nauczycieli. Z przekąsem można by nawet powiedzieć, że tematyka agresji jest „trendy”. Dlatego tym bardziej dziwi niedostatek lub nieumiejętność użycia elementarnej wiedzy, akurat z tego zakresu. Czy nauczycielki i studentki lepiej radzą sobie w innych mniej medialnych obszarach? Wątpliwości te każą nie tylko głębiej zastanowić się nad zakresem i sposobami kształcenia oraz doskonalenia nauczycieli, jak to czyni Józef Półturzycki ${ }^{50} \mathrm{i}$ inni, ale też próbować na bieżąco je modyfikować.

Przedstawiłam niektóre i bardzo różne zakresowo relacje z obserwacji i badań związanych z edukacją przedszkolaków i najmłodszych uczniów, a właściwie to w jaki sposób studentki pedagogiki odbierają tę rzeczywistość. To fragmentaryczny i subiektywny obraz widziany oczami osób bardziej niż inne obeznanych i zainteresowanych zachodzącymi w przedszkolu i szkole procesami. Ponadto, edukacja ta obserwowana była i oceniania przez pryzmat moich osobistych doświadczeń i sądów. Nawiasem mówiąc - w moim przekonaniu nie sposób rzeczywistości wychowawczej obiektywnie obserwować i analizować z zewnątrz, gdyż świat ten nie istnieje poza nami. Siłą rzeczy, zarówno badacze, studenci, jak i nauczyciele przedstawiaja go nie takim jaki on faktyczne jest, ale takim jakie mu nadają znaczenia ${ }^{51}$. Nie tylko są one generowane w określonym społeczno-kulturowym kontekście, ale ten kontekst systematycznie zmieniają. Wpływa to $\mathrm{z}$ kolei na modyfikowanie nadanych już sensów

${ }^{47}$ J. S. Bruner, Poza dostarczone informacje, Warszawa 1978, s. 662.

${ }^{48}$ J. S. Bruner, Kultura edukacji, Kraków 2006, s. 37.

${ }^{49}$ Por. Rozporządzenia $w$ sprawie podstawy programowej z ostatnich lat.

${ }^{50}$ J. Półturzycki, Standardy ksztatcenia a kompetencje nauczycieli, [w:] K. Żegnałek (red.), Kompetencje nauczyciela edukacji...

${ }^{51}$ E. Babbie. Badania spoteczne w praktyce, Warszawa 2003, s. 317, [za:] A. Schutz, The Phenomenology of the Social Word, Northwestern University Press, Evanston, III. 
i wytwarzanie nowych. Oznacza to, m.in., że również przywołane wyżej egzemplifikacje praktyki i myślenia pedagogicznego stanowią inny jakościowo kontekst dla konstruowania (rekonstruowania) wiedzy o wczesnej edukacji oraz kształceniu nauczycieli.

EwA ARCISZEWSKA

\section{Early education of child from the perspective of selected experiences and student research}

This article is a report of individuating qualititative research on perception of early education by 55 senior students of the full-time and part-time BA programme of studies preparing for teaching kindergarten and early education. Quoted and interpreted are only some of the very diverse examples of events, descriptions of student observations and research conducted in the years 2008-2010 in Warsaw and its surroundings. They indicate that education on this level is a highly formalized process and focused on observable behavior of the child, leading to a measureable result. Additionally, both the teachers and the students participating in the study have shown a significant lack of psychopedagogical knowledge and low reflexivity. Unfortunately, these conclusions are consistent with the critical assessments formulated by the scientific community on the basis of research and analysis undertaken due to reforms of the education system in recent years. 